\title{
Novel naphthylpyridines from cobalt-catalyzed cyclotrimerization of a chiral diyne
}

\author{
Volkmar Trommer ${ }^{1} \cdot$ Fabian Fischer $^{1} \cdot$ Marko Hapke $^{1,2}$ (B)
}

Received: 3 October 2017/ Accepted: 16 October 2017/Published online: 28 November 2017

(c) The Author(s) 2017. This article is an open access publication

\begin{abstract}
The concise synthesis of a novel chiral diyne substrate for the assembly of chiral naphthylpyridines was described and different conditions for the cobalt-catalyzed co-cyclotrimerization with nitriles investigated. The products are novel naphthylpyridines possessing configurationally stable biaryl axes.

Graphical abstract

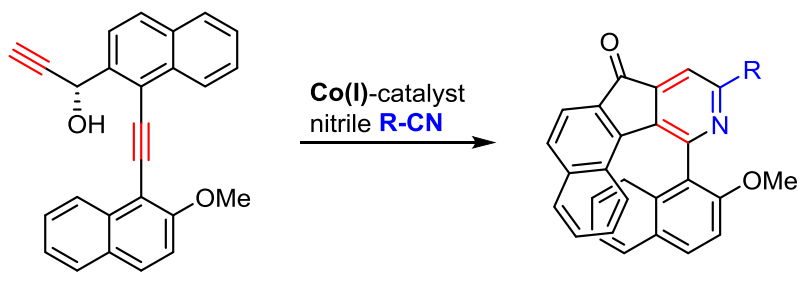

Keywords Biaryls $\cdot$ Cycloadditions · Catalysis . Heterocycles · Alkynes

Electronic supplementary material The online version of this article (doi:10.1007/s00706-017-2083-9) contains supplementary material, which is available to authorized users.

Marko Hapke

marko.hapke@jku.at

1 Leibniz-Institut für Katalyse an der Universität Rostock (LIKAT), Albert-Einstein-Strasse 29a, 18059 Rostock, Germany

2 Institut für Katalyse (INCA), Johannes Kepler Universität Linz, Altenberger Strasse 69, 4040 Linz, Austria

\section{Introduction}

Helicenes and axially chiral biaryls constitute two kinds of chirality which are manifested in many structurally fascinating examples. Chiral and achiral biaryl compounds were found or play a role in many natural products [1-3], in drug discovery $[4,5]$, or as a key building block of many chiral ligands for stereoselective catalysis [6-8], to name a few examples. The arsenal of synthetic methods for the atroposelective synthesis of biaryls has become extremely broad especially during the recent two decades [9]. Helicenes have found application in many similar areas of application due to their unique helical chirality as well as rigid conjugated structures and different approaches for their synthesis have been explored [10-13]. Combining the ease of functional group introduction and modification in the biaryl backbone with elements contributing to the large configurational stability of many higher helicenes can be beneficial to the construction of molecular ligand platforms. An attractive and in recent years significantly developed access to helicenes and biaryls was found in the application of the $[2+2+2]$ cycloaddition reaction [14]. Especially intramolecular transformations of di-, tri-, and oligoalkynes were developed as a systematic access, employing a wide range of transition metal catalysts [15]. The assembly of chiral helicenes by cyclotrimerization reactions was realized with different metal catalysts [16-18].

We have investigated the asymmetric synthesis of naphthyl isoquinolines by $[2+2+2]$ cycloaddition of diynes and nitriles applying chiral indenyl $\mathrm{Co}(\mathrm{I})$-catalysts, especially also under photochemical conditions $[19,20]$. The construction of naphthyl pyridines with annellated, unsymmetrical five-membered rings by the 


\section{Scheme 1}

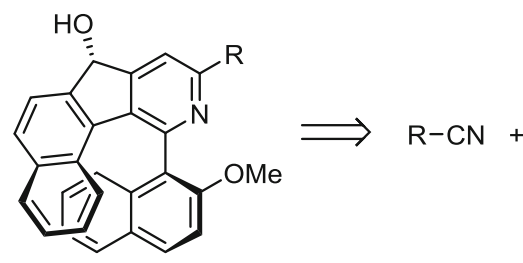

I<smiles>COc1ccc2ccccc2c1I</smiles>

1

$+$<smiles>COC(=O)c1ccc2ccccc2c1Br</smiles>

2<smiles>C#CC(=O)c1ccc2ccccc2c1C#Cc1c(OC)ccc2ccccc12</smiles>

8

$\Downarrow$<smiles>COC(=O)c1ccc2ccccc2c1C#Cc1c(OC)ccc2ccccc12</smiles>

Co(I)-mediated cyclotrimerization of the corresponding diynes and nitriles was essential during an investigation on epimerization barriers of this class of compounds [21]. Application of the chiral indenyl Co(I)-complex mentioned above in the synthesis of tetrahydro [6] helicene from triynes was investigated by us and the group of Stará as well [22].

In the present work, we planned to exploit our synthetic experience in the synthesis of alkyne derivatives and aimed at synthesizing chiral diynes as precursor molecules for highly sterically hindered diastereomeric naphthyl pyridine atropisomers, which should be separable by e.g. chromatography on silica gel. The following section describes the synthesis of the substrates and surprising results for the cyclotrimerization step.

Scheme 2

\section{Results and discussion}

The work was initiated with the planning of an efficient synthetic access for the diyne substrate leading to the envisioned product I. In Scheme 1 the retrosynthetic analysis is shown. The synthesis would start from the two halogenated naphthalene building blocks $\mathbf{1}$ and $\mathbf{2}$ from where subsequent introduction of the alkyne moieties will lead to substituted alkyne $\mathbf{4}$ and subsequently diynes $\mathbf{8}$ and 9. The final step will be a transition metal-catalyzed $[2+2+2]$ cycloaddition reaction with a nitrile, leading to the finally assembled product I containing a chiral secondary alcohol as a second chiral element beside the biaryl axis. This should potentially lead to separable diastereomeric atropisomers [23].

The synthesis of the building blocks 1 [24] and 2 [25] has been already described in the literature and previous work, as has the ethinylation of 1, yielding 1-ethinyl-2methoxynaphthalene (3) as the terminal alkyne [26]. Coupling of $\mathbf{2}$ and $\mathbf{3}$ was initially pursued by a copper-free cross-coupling approach reported by Stará et al. (Scheme 2) [27]. However, using piperidine or diisopropylamine (DIPA) as amine base at higher reaction temperatures required for bromides only 25 or $28 \%$ yield of 4 were obtained, in the first case together with $33 \%$ of methyl 1-(piperidin-1-yl)-2-naphthoate as byproduct from the amination of the bromonaphthalene. Instead, application of convenient $\mathrm{Cu}-\mathrm{Pd}$-mediated Sonogashira conditions for the coupling successfully furnished target compound 4 with superior $87 \%$ yield (Scheme 2).

Pure bisnaphthylalkyne $\mathbf{4}$ was isolated as yellow needles by crystallization from ethyl acetate, allowing also to gather single crystals suitable for X-ray structure analysis (Fig. 1). The substituents on the naphthyl groups point to opposite directions with the naphthyl systems being coplanar oriented to each other.

Further manipulation of $\mathbf{4}$ required the transformation of the ester moiety into a Weinreb amide for the nucleophilic
Cond. A:

$\mathrm{Pd}\left(\mathrm{PPh}_{3}\right)_{4}$,

Piperidine or DIPA,

$60{ }^{\circ} \mathrm{C}, 12 \mathrm{~h}$

Cond. B:

$\mathrm{Pd}\left(\mathrm{PPh}_{3}\right)_{4}$, Cul,

DIPA, THF,

$60{ }^{\circ} \mathrm{C}, 12 \mathrm{~h}$

Yields:

Cond. A: $25-28 \%$

Cond. B: $87 \%$<smiles>COC(=O)c1ccc2ccccc2c1C#Cc1c(OC)ccc2ccccc12</smiles>

4 


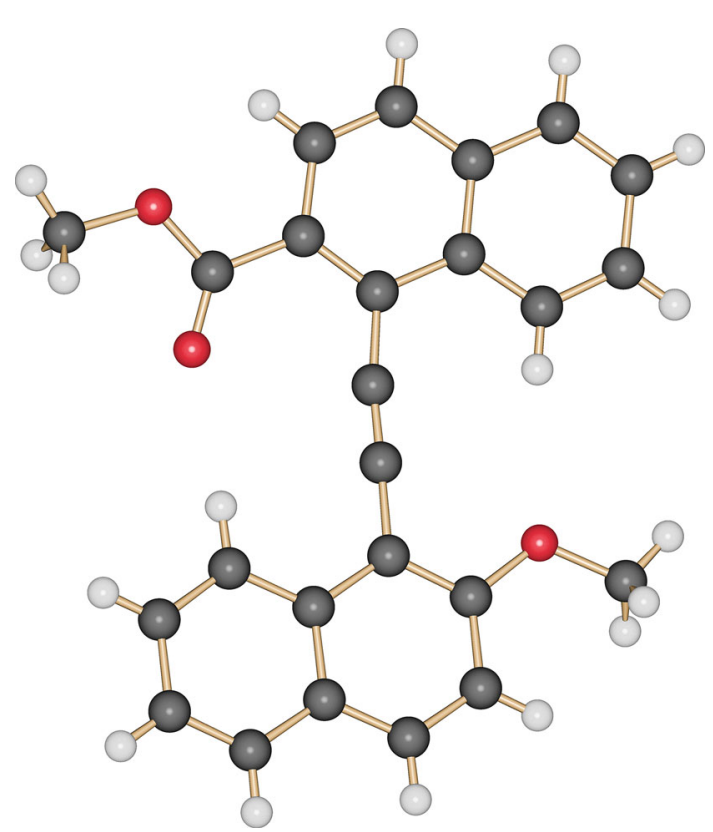

Fig. 1 Molecular structure of compound $\mathbf{4}$ as determined by single crystal X-ray diffraction

addition of the second alkyne. The sequence was started by basic hydrolysis of the ester group with nearly quantitative yield of the carboxylic acid $\mathbf{5}$. The classical approach of turning 5 into the acid chloride using thionyl chloride, followed by reaction with $\mathrm{N}, \mathrm{O}$-dimethylhydroxylamine hydrochloride (6) in the presence of $\mathrm{NEt}_{3}$ was not successful here. Fortunately application of a synthetic variation by $\mathrm{Fu}$ et al. gave the amide $\mathbf{7}$ in excellent yield of up to $86 \%$, circumventing the preparation of the acid chloride (Scheme 3) [28]. The presence of triethylamine was found to be essential to promote the reaction, when using the hydrochloride, while otherwise no conversion was observed.

Subsequently the reaction of Weinreb amide 7 with lithiated trimethylsilylacetylene and the subsequent reduction of the synthesized ketoalkyne $\mathbf{8}$ was investigated (Scheme 4). Li-TMS-acetylide was prepared following a standard procedure and the rapid reaction with 7 was quantitative, surprisingly yielding both after work-up, the expected product TMS-8 and the desilylated 8 with a 70:30 ratio. Subsequent desilylation of isolated TMS-8 with KF was not met with success, as several products resulted from the reaction, possibly due to the decomposition of the activated triple bond. Prolonged reaction times of the desilylation in methanol led to double addition of $\mathrm{MeOH}$ to the activated triple bond. As it was planned to introduce a second element of chirality for later separation of the resulting diastereomeric atropisomers, the reduction of the ketoalkyne was pursued using $(R)$-Alpine-Borane ${ }^{\circledR}$ at mild conditions. The reaction worked extremely well on both TMS-8 and 8, and for TMS-8 the follow-up TMSdeprotection with KF from the crude product of the reduction proceeded as usual, allowing the isolation of enantiomerically pure 9 with $96 \%$ yield over two steps. The reduction of the keto group in isolated $\mathbf{8}$ also gave pure 9 with $96 \%$ yield.

Having isolated 9 in our hands, we could study the behavior in the $[2+2+2]$ cycloaddition reaction with different nitriles and catalysts. The first experiments utilized $\mathrm{CpCo}$ (COD) (CAT1) as catalyst under photochemical conditions and $\mathrm{CpCo}\left[\mathrm{P}(\mathrm{OEt})_{3}\right]$ (trans $\left.-\mathrm{MeO}_{2} \mathrm{CH}=\mathrm{CHCO}_{2} \mathrm{Me}\right) \quad$ (CAT2) under thermal conditions (Scheme 5) [21]. The latter catalyst has recently been developed in our laboratory and is commercially available [29].

Several different nitriles were investigated and in general good yields of products were observed. A rather interesting general observation in these cyclization reactions is the dehydrogenation of the secondary alcohol group forming a keto group in the cyclization products rac-10a-10e, which prevents the potential isolation and separation of the intended diastereomeric atropisomers. Therefore, also reduction using an achiral hydride source such as $\mathrm{NaBH}_{4}$ instead of Alpine-Borane ${ }^{\circledR}$ would be possible due to the later autoreoxidation. The reoxidation of the hydroxyl function might be favored by the formation of a conjugated system in the backbone of the molecule. However, the cyclization of diyne 9 under photochemical conditions proceeded very well in both cases using $\mathrm{MeCN}$ and $\mathrm{PhCN}$ as cyclization

Scheme 3

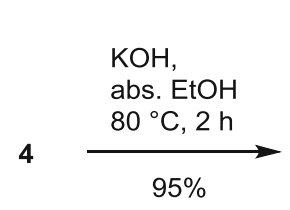<smiles>COc1ccc2ccccc2c1C#Cc1c(C(=O)O)ccc2ccccc12</smiles>

5

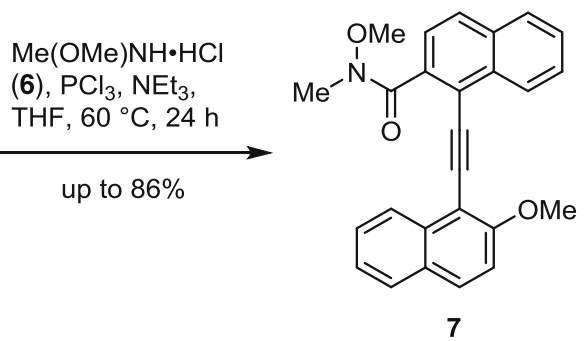


Scheme 4
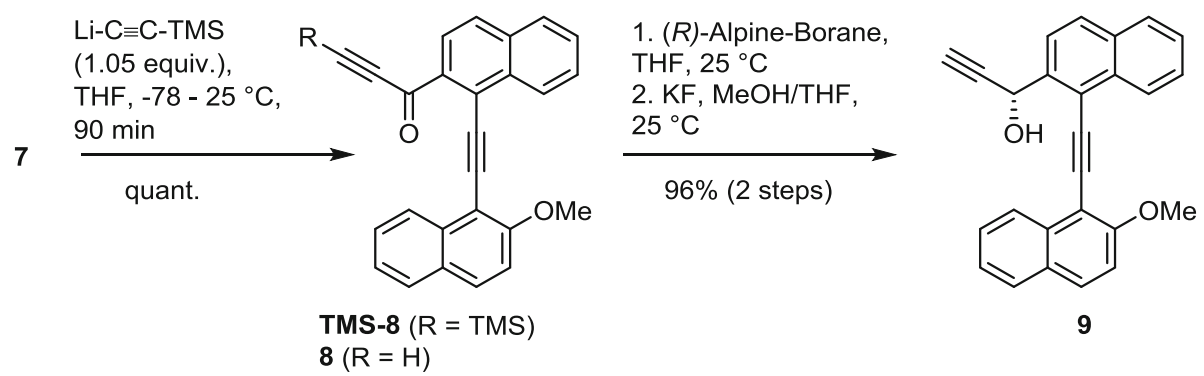

Scheme 5<smiles>C#C[C@H](O)c1ccc2ccccc2c1C#Cc1c(OC)ccc2ccccc12</smiles>

Cvclization Cond. 1: CAT1, THF, hv, $25^{\circ} \mathrm{C}$, $24 \mathrm{~h}, \mathrm{R}-\mathrm{CN}$

Cyclization Cond. 2 CAT2, toluene, $100^{\circ} \mathrm{C}$, 24 h, R-CN

\begin{tabular}{cll} 
Cat./Cond. & Cyclization product & Yield \\
\hline CAT1/1 & rac-10a $(\mathrm{R}=\mathrm{Ph})$ & $70 \%$ \\
CAT2/2 & rac-10a $(\mathrm{R}=\mathrm{Ph})$ & $62 \%$ \\
CAT1/1 & rac-10b $(\mathrm{R}=\mathrm{Me})$ & $69 \%$ \\
CAT2/2 & rac-10b $(\mathrm{R}=\mathrm{Me})$ & $48 \%$ \\
CAT2/2 & rac-10c $(\mathrm{R}=t$ - $\mathrm{Bu})$ & $39 \%$ \\
CAT2/2 & rac-10d $(\mathrm{R}=$ piperidinyl) & $62 \%$ \\
CAT2/2 & rac-10e $(\mathrm{R}=2$-naphthyl) & $37 \%(\mathrm{MW})$ \\
CAT2/2 & rac-10f $(\mathrm{R}=1$-benzyloxy & no reaction \\
& -2-naphthyl) \\
\hline
\end{tabular}

CAT1: $\mathrm{CpCo}(\mathrm{COD})$; CAT2: $\mathrm{CpCo}\left[\mathrm{P}(\mathrm{OEt})_{3}\right]$ (trans $\left.-\mathrm{MeO}_{2} \mathrm{CCH}=\mathrm{CHCO}_{2} \mathrm{Me}\right)$

substrates, yielding up to $70 \%$ yield of racemic rac-10a and $\mathrm{rac}-\mathbf{1 0 b}$. Yields under thermal conditions $\left(100^{\circ} \mathrm{C}\right.$, oil bath) using the air-stable catalyst CAT2 proceeded with slightly lower yield for $\mathrm{rac}-\mathbf{1 0 a}$ and $48 \%$ for $\mathrm{rac}$ 10b. No detrimental effect of the formal oxidation of the hydroxyl group on the cyclizations was identified at this point. Experiments using ketoalkyne $\mathbf{8}$ as substrate with catalysts CAT1 and CAT2 under the conditions mentioned above with $\mathrm{PhCN}$ only gave significantly lower yields of rac-10a (25-30\%). The application of other nitriles using CAT2 under thermal conditions led to the $t$-butyl-(rac-10c) or piperidinyl-(rac-10d)-substituted biaryls in acceptable to good yields. The reaction of $\mathbf{9}$ with 2-cyanonaphthalene using CAT2 under conventional conditions gave just $17 \%$ yield of product $\mathrm{rac}-\mathbf{1 0 e}$, while applying microwave heating (MW) to $110{ }^{\circ} \mathrm{C}$ for $1 \mathrm{~h}$ improved the yield of rac-10e to $37 \%$ yield. The reaction using 1-benzyloxy-2-cyanonaphthalene, however, gave no cyclization product at all under the investigated conditions.

\section{Conclusion}

We presented the concise synthesis of a novel chiral diyne precursor molecule starting from simple arene building blocks for $[2+2+2]$ cycloadditions. Reaction with different nitriles under thermally and photochemically assisted cobalt catalysis gave the respective annulated naphthylpyridines in good yields, while the chiral hydroxyl group was unexpectedly reoxidized to the keto group during the cyclization process. The synthesis allowed access to heterocyclic biaryl compounds possessing a stable, sterically hindered biaryl axis, which should be attractive for the synthesis of novel ligand backbones.

\section{Experimental}

The NMR spectra were in general recorded at $298 \mathrm{~K}$ and the individual measurement conditions given with the data. Chemical shifts are reported in ppm relative to the ${ }^{1} \mathrm{H}$ and 
${ }^{13} \mathrm{C}$ residue signals of the deuterated solvent (deuterochloroform: $\delta=7.26 \mathrm{ppm}$ for ${ }^{1} \mathrm{H}$ and $\delta=77.16 \mathrm{ppm}$ for ${ }^{13} \mathrm{C}$ ). Mass spectra were obtained with a mass spectrometer at an ionizing voltage of $70 \mathrm{eV}$ for EI. Only characteristic fragments containing the isotopes of highest abundance are listed. Relative intensities in percentages are given in parentheses. High-resolution mass spectroscopy (HRMS) analyses were performed using electrospray ionization/time-of-flight (ESI-TOF) mass spectrometry or electron ionization (EI) with a sector field mass analyzer. For the photochemistry two halogen lamps (460 W each) have been used for the irradiation of the thermostated Schlenk-type reaction vessel [21]. For microwave experimentation CEM Discover $\mathrm{SP}^{\mathrm{TM}}$ with glass tubes was used. All reactions were carried out in an argon atmosphere, using standard techniques in dry, oxygen-free solvents. Chromatographic purifications were done with $240-400$ mesh silica gel or on an automated flash-chromatography system. $\mathrm{CpCo}(\mathrm{COD}), \mathrm{Pd}\left(\mathrm{PPh}_{3}\right)_{4}$, methyl 1-bromo-2-naphthoate (2) [25], and 1-ethinyl-2-methoxynaphthalene (3) [26] were synthesized according to known procedures. The synthesis and catalytic properties of the air-stable precatalyst $\mathrm{CpCo}\left[\mathrm{P}(\mathrm{OEt})_{3}\right]\left(\right.$ trans $\left.-\mathrm{MeO}_{2} \mathrm{CH}=\mathrm{CHCO}_{2} \mathrm{Me}\right)[\mathrm{CAT} 2]^{1}$ have been reported by us recently [29]. All other starting materials and compounds were commercially available and have been used as received.

\section{Methyl 1-[(2-methoxynaphthalen-1-yl)ethynyl]-2-naph-} thoate $\left(4, \mathrm{C}_{25} \mathrm{H}_{18} \mathrm{O}_{3}\right)$

Coupling conditions A $132.6 \mathrm{mg}$ methyl 1-bromo-2-naphthoate $(2,0.50 \mathrm{mmol})$ together with $29 \mathrm{mg}\left[\mathrm{Pd}\left(\mathrm{PPh}_{3}\right)_{4}\right]$ ( $0.05 \mathrm{mmol}, 5 \mathrm{~mol} \%)$ were dissolved in $2 \mathrm{~cm}^{3}$ diisopropylamine under an inert atmosphere and heated in an oil bath to $45^{\circ} \mathrm{C}$, until a clear solution resulted. Afterwards a solution of $91.1 \mathrm{mg}$ 1-ethynyl-2-methoxynaphthalene (3, $0.50 \mathrm{mmol})$ in a mixture of diisopropylamine and THF $\left(1 \mathrm{~cm}^{3}\right.$ each) was added and the reaction mixture stirred over night at $50{ }^{\circ} \mathrm{C}$. After cooling the solution was filtered, the filter residue washed with $5 \mathrm{~cm}^{3}$ toluene/petrolether $(1: 1 \mathrm{v} / \mathrm{v})$ and the solvents removed in vacuo. The crude product was purified by flash column chromatography on silica gel ( $n$-hexane/ethyl acetate, $100 \% \rightarrow 66 \% \mathrm{v} / \mathrm{v})$, yielding $51 \mathrm{mg}$ ( $28 \%$ yield) pure compound. Conducting the reaction with piperidine instead of diisopropylamine gave 25\% yield of 4 and in addition methyl 1-(piperidin-1yl)-2-naphthoate $(33 \%)$ as amination byproduct.

Coupling conditions B $764 \mathrm{mg}$ compound 3 $(2.88 \mathrm{mmol}), 57.60 \mathrm{mg}$ CuI $(0.29 \mathrm{mmol}, 10 \mathrm{~mol} \%)$ and $167 \mathrm{mg}$ catalyst $\left[\mathrm{Pd}\left(\mathrm{PPh}_{3}\right)_{4}\right](0.14 \mathrm{mmol}, 5 \mathrm{~mol} \%)$ were

\footnotetext{
${ }^{1}$ Commercially available from TCI, order no. C3165, CAS no. 1487195-87-8 (http://www.tcichemicals.com/).
}

suspended under an inert atmosphere in $8 \mathrm{~cm}^{3}$ diisopropylamine and the reaction mixture heated to $45^{\circ} \mathrm{C}$, until a clear solution resulted. A second solution prepared under an inert atmosphere of $525 \mathrm{mg} 2(2.88 \mathrm{mmol})$ in $4 \mathrm{~cm}^{3}$ diisopropylamine and $8 \mathrm{~cm}^{3}$ THF was then added and stirred over night at $60{ }^{\circ} \mathrm{C}$. Work-up of the crude reaction mixture like described under conditions $\mathrm{A}$ again using a mixture of toluene/petrolether $\left(1: 1 \mathrm{v} / \mathrm{v}, 50 \mathrm{~cm}^{3}\right)$ for washing of the solid residuals, followed by flash column chromatography yielded the pure product $(920 \mathrm{mg}, 87 \%$ yield).

M.p.: $\quad{ }^{135-136}{ }^{\circ} \mathrm{C} ; \quad{ }^{1} \mathrm{H} \quad \mathrm{NMR} \quad\left(\mathrm{CDCl}_{3}, \quad 300 \mathrm{MHz}\right)$ : $\delta=4.09\left(\mathrm{OCH}_{3}, 3 \mathrm{H}\right), 4.17\left(\mathrm{COOCH}_{3}, 3 \mathrm{H}\right), 7.34(\mathrm{~d}$, $J=9.1 \mathrm{~Hz}, \operatorname{Ar}-H, 1 \mathrm{H}), 7.43(\mathrm{ddd}, J=8.2,6.8,1.2 \mathrm{~Hz}$, Ar- $H, 1 \mathrm{H}), 7.70$ (ddd, $J=8.4,6.8,1.6 \mathrm{~Hz}, \operatorname{Ar}-H, 1 \mathrm{H}$ ), 7.60-7.68 (m, Ar- $H, 2 \mathrm{H}), 7.81-7.92(\mathrm{~m}, \mathrm{Ar}-\mathrm{H}, 4 \mathrm{H}), 8.05$ $(\mathrm{d}, J=8.7, \operatorname{Ar}-H, 1 \mathrm{H}), 8.72(\mathrm{~d}, J=8.3 \mathrm{~Hz}, \operatorname{Ar}-H, 1 \mathrm{H})$, $9.11(\mathrm{~d}, J=8.6 \mathrm{~Hz}, \mathrm{Ar}-H, 1 \mathrm{H}) \mathrm{ppm} ;{ }^{13} \mathrm{C} \mathrm{NMR}\left(\mathrm{CDCl}_{3}\right.$, $75 \mathrm{MHz}): \delta=52.6 \quad\left(\mathrm{COOCH}_{3}\right), \quad 56.8\left(\mathrm{OCH}_{3}\right), \quad 95.8$ $(\mathrm{CC} \equiv \mathrm{CC}), 96.5(\mathrm{CC} \equiv C \mathrm{C}), 107.0(\mathrm{Ar}-C), 112.7(\mathrm{Ar}-C)$, $123.4(\mathrm{Ar}-C), 124.5(\mathrm{Ar}-C), 126.1$ (2x Ar-C), $127.6(\mathrm{Ar}-C)$, $127.8(\mathrm{Ar}-C), 128.0(\mathrm{Ar}-C), 128.2(2 \mathrm{x} \mathrm{Ar}-C), 128.3(\mathrm{Ar}-C)$, 128.7 (Ar-C), 128.7 (Ar-C), 129.6 (Ar-C), 130.9 (Ar-C), 133.9 (Ar-C), 134.8 (Ar-C), 134.9 (Ar-C), 159.9 (Ar$\left.\mathrm{COCH}_{3}\right), \quad 167.6 \quad\left(\mathrm{COOCH}_{3}\right)$ ppm; HRMS (ESI): $\left(\left[\mathrm{C}_{25} \mathrm{H}_{18} \mathrm{O}_{3}\right]+\mathrm{H}\right)^{+}$calc. 367.1329, found 367.1328; $\left(\left[\mathrm{C}_{25} \mathrm{H}_{18} \mathrm{O}_{3}\right]+\mathrm{Na}\right)^{+}$calc. 389.1148 , found 389.1148 .

CCDC-1550069 contains the supplementary crystallographic data for compound $4\left(\mathrm{C}_{25} \mathrm{H}_{18} \mathrm{O}_{3}\right)$. These data can be obtained free of charge from The Cambridge Crystallographic Data Centre via http://www.ccdc.cam.ac.uk/ data_request/cif.

1-[(2-Methoxynaphthalen-1-yl)ethynyl]-2-naphthoic acid $\left(\mathbf{5}, \mathrm{C}_{24} \mathrm{H}_{16} \mathrm{O}_{3}\right)$

To a solution of $2.63 \mathrm{~g} \mathrm{KOH} \mathrm{(46.87} \mathrm{mmol,} 20$ equiv.) in $24 \mathrm{~cm}^{3}$ abs. EtOH $0.86 \mathrm{mg}$ of compound $4(2.35 \mathrm{mmol})$ was added and the reaction mixture stirred for $2 \mathrm{~h}$ at $80{ }^{\circ} \mathrm{C}$ oil-bath temperature. The colour of the mixture changed from milky-grey to into dark purple and a solid was precipitating out of solution. For work-up the reaction mixture was diluted with $250 \mathrm{~cm}^{3}$ water and was washed with $\mathrm{Et}_{2} \mathrm{O}$ three times $\left(200 \mathrm{~cm}^{3}\right.$ each). The aqueous solution with the purple precipitate was acidified with conc. $\mathrm{HCl}(\mathrm{pH}<2)$, whereupon a colour change to yellow was observed. The suspension with the yellow solid was extracted with $\mathrm{Et}_{2} \mathrm{O}$ three times $\left(200 \mathrm{~cm}^{3}\right.$ each) and after desiccation of the combined phases over $\mathrm{Na}_{2} \mathrm{SO}_{4}$ the solvent was removed in vacuo. Pure product $\mathbf{5}$ was isolated as yellow solid (786 mg, 95\%). M.p.: $179{ }^{\circ} \mathrm{C}$ (decomposition); ${ }^{1} \mathrm{H}$ NMR $\left(\left(\mathrm{CD}_{3}\right)_{2} \mathrm{SO}, 300 \mathrm{MHz}\right): \delta=4.20(\mathrm{~s}$, $\left.\mathrm{OCH}_{3}, 3 \mathrm{H}\right), 7.43-7.51(\mathrm{~m}, \mathrm{Ar}-\mathrm{H}, 1 \mathrm{H}), 7.57-7.66$ (m, Ar- $\mathrm{H}$, 2H), 7.71-7.78 (m, Ar- $H, 1 \mathrm{H}), 7.82-7.89(\mathrm{~m}, \mathrm{Ar}-H, 1 \mathrm{H})$, 
7.93-7.99 (m, Ar- $H, 1 \mathrm{H}), 8.02-8.12$ (m, Ar- $H, 4 \mathrm{H}), 8.72$ $(\mathrm{d}, J=8.4 \mathrm{~Hz}, \operatorname{Ar}-H, 1 \mathrm{H}), 9.07(\mathrm{~d}, J=8.4 \mathrm{~Hz}, \operatorname{Ar}-H$, 1H), 13.5 (bs, $\mathrm{OH}$ ) ppm; MS (EI): $\mathrm{m} / z(\%)=352(100)$, 293 (95), 281 (28), 252 (18); HRMS (EI, $70 \mathrm{eV}$ ): $\left[\mathrm{C}_{24} \mathrm{H}_{16} \mathrm{O}_{3}\right]$ calc. 352.1094, found 352.1093 .

$N$-Methoxy-1-[(2-methoxynaphthalen-1-yl)ethynyl]- $N$ methyl-2-naphthamide $\left(\mathbf{7}, \mathrm{C}_{26} \mathrm{H}_{21} \mathrm{NO}_{3}\right)$

Optimized procedure: A solution of $1.80 \mathrm{~g} 5(5.10 \mathrm{mmol})$ and $1.50 \mathrm{~g} \mathrm{~N}, O$-dimethylhydroxylamine hydrochloride $(\mathbf{6}$, $15.0 \mathrm{mmol})$ in $30 \mathrm{~cm}^{3} \mathrm{THF}$ at $0{ }^{\circ} \mathrm{C}, 2.80 \mathrm{~cm}^{3} \mathrm{NEt}_{3}$ $(20.0 \mathrm{mmol})$, and $0.44 \mathrm{~cm}^{3} \mathrm{PCl}_{3}(5.0 \mathrm{mmol})$ were added dropwise subsequently via syringe. The reaction mixture was stirred for $24 \mathrm{~h}$ at $60{ }^{\circ} \mathrm{C}$. After $12 \mathrm{~h}$ additional amounts of $\mathrm{NEt}_{3}\left(2.80 \mathrm{~cm}^{3}, 20.0 \mathrm{mmol}\right)$ and $\mathrm{PCl}_{3}$ $\left(0.44 \mathrm{~cm}^{3}, 5.0 \mathrm{mmol}\right)$ were added. After cooling the reaction mixture was quenched with sat. $\mathrm{NaHCO}_{3}$, extracted several time with a mixture of THF/ethyl acetate $(1: 1 \mathrm{v} / \mathrm{v})$ and finally washed with brine. After drying over $\mathrm{Na}_{2} \mathrm{SO}_{4}$ the solvent was removed in vacuo. The crude product was further purified over silica gel by column chromatography (cyclohexane/ethyl acetate $=1: 1 \mathrm{v} / \mathrm{v}, 1 \%$ $\left.\mathrm{NEt}_{3}\right)$. The yield obtained was $1.46 \mathrm{~g}(72 \%)$, on a smaller experimentation scale $(0.5 \mathrm{mmol}$ acid $) 86 \%$ product were

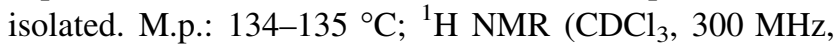
$333 \mathrm{~K}): \delta=3.45\left(\mathrm{~s}, \mathrm{NCH}_{3}, 3 \mathrm{H}\right), 3.64\left(\mathrm{~s}, \mathrm{NOCH}_{3}, 3 \mathrm{H}\right)$, $4.13\left(\mathrm{~s}, \mathrm{OCH}_{3}, 3 \mathrm{H}\right), 7.30(\mathrm{~d}, J=9.1 \mathrm{~Hz}, \mathrm{Ar}-H, 1 \mathrm{H}), 7.41$ (ddd, $J=7.6,6.8,1.3 \mathrm{~Hz}$, Ar- $H, 1 \mathrm{H}), 7.51(\mathrm{~d}, J=8.4 \mathrm{~Hz}$, Ar- $H, 1 \mathrm{H}$ ), 7.55-7.64 (m, Ar- $H, 2 \mathrm{H}), 7.67$ (ddd, $J=8.3$, 6.8, $1.4 \mathrm{~Hz}, \operatorname{Ar}-H, 1 \mathrm{H}), 7.80(\mathrm{~d}, J=8.0 \mathrm{~Hz}, \operatorname{Ar}-H, 1 \mathrm{H})$, 7.83-7.92 (m, Ar- $H, 3 \mathrm{H}), 8.48$ (dd, $J=8.4,1.0 \mathrm{~Hz}, \mathrm{Ar}-H$, $1 \mathrm{H}), 8.81(\mathrm{~d}, J=8.4 \mathrm{~Hz}$, Ar- $H, 1 \mathrm{H}) \mathrm{ppm} ;{ }^{13} \mathrm{C} \mathrm{NMR}$ $\left(\mathrm{CDCl}_{3}, 75 \mathrm{MHz}\right): \delta=33.4\left(\mathrm{NCH}_{3}\right), 57.1\left(\mathrm{OCH}_{3}\right), 61.4$ $\left(\mathrm{NOCH}_{3}\right), 93.8$ (CCCC), 94.7 (CCCC), 113.4 (Ar-C), $119.4(\mathrm{Ar}-\mathrm{C}), 123.8(\mathrm{Ar}-\mathrm{C}), 124.6(\mathrm{Ar}-\mathrm{C}), 125.9(\mathrm{Ar}-\mathrm{C})$, 127.3 (Ar-C), 127.4 (Ar-C), 127.6 (Ar-C), 127.7 (Ar-C), 128.2 (Ar-C), 128.3 (Ar-C), $128.4(\mathrm{Ar}-C), 129.0$ (Ar-C), 130.7 (Ar-C), 133.4 (Ar-C), 133.5 (Ar-C), 134.9 (Ar-C), $159.9\left(\mathrm{Ar}-\mathrm{COCH}_{3}\right) \mathrm{ppm}$ (not all expected signals were observed); ${ }^{13} \mathrm{C}$ NMR (toluene- $d_{8}, \quad 75 \mathrm{MHz}, 373 \mathrm{~K}$ ): $\delta=33.6\left(\mathrm{NCH}_{3}\right.$, detection of the N-Me group not possible unambiguously); MS (EI): $m / z$ (\%) = 364 (100), 335 (39), 276 (24), 263 (32), 132 (26); HRMS (ESI): $\left(\left[\mathrm{C}_{26} \mathrm{H}_{21-}\right.\right.$ $\left.\left.\mathrm{NO}_{3}\right]+\mathrm{H}\right)^{+} \quad$ calc. 396.1594, found 396.1596; $\left(\left[\mathrm{C}_{26} \mathrm{H}_{21} \mathrm{NO}_{3}\right]+\mathrm{Na}\right)^{+}$calc. 418.1414, found 418.1418; IR (ATR): $\bar{v}=424,466,549,556,744,753,812,1258$, $1270,1639 \mathrm{~cm}^{-1}$.

1-[1-[(2-Methoxynaphthalen-1-yl)ethynyl]naphthalen-2-yl]3-(trimethylsilyl)prop-2-yn-1-one (TMS-8, $\mathrm{C}_{29} \mathrm{H}_{24} \mathrm{O}_{2} \mathrm{Si}$ ) and 1-[1-[(2-methoxynaphthalen-1-yl)ethynyl]naphthalen-2-yl] prop-2-yn-1-one $\left(\mathbf{8}, \mathrm{C}_{26} \mathrm{H}_{16} \mathrm{O}_{2}\right)$

In a secured Schlenk flask a solution of $0.19 \mathrm{~cm}^{3}$ trimethylsilylacetylene $(1.33 \mathrm{mmol})$ in $8 \mathrm{~cm}^{3}$ THF was cooled to $-78{ }^{\circ} \mathrm{C}$ and $0.87 \mathrm{~cm}^{3} n$-BuLi $(1.39 \mathrm{mmol}$, $1.6 \mathrm{M}$ in $\mathrm{THF}$ ) added via syringe. The reaction mixture was allowed to warm to room temperature and stirred for further $20 \mathrm{~min}$. Afterwards the solution was cooled again to $-78^{\circ} \mathrm{C}$ and a solution of $7(0.50 \mathrm{~g}, 1.26 \mathrm{mmol})$ in $8 \mathrm{~cm}^{3}$ THF was added dropwise. The reaction mixture was stirred for additional $90 \mathrm{~min}$ at room temperature after completed addition, then quenched with water and extracted several times with ethyl acetate. The combined organic phases were washed with brine, dried over $\mathrm{Na}_{2} \mathrm{SO}_{4}$, and the solvent removed in vacuo. Chromatographic purification at silica gel (cyclohexane/ethyl acetate 6:1 v/v) yielded compounds TMS-8 (383 mg, 70\%, yellow-orange solid) and $8(137 \mathrm{mg}, 30 \%$, red-orange solid).

Compound TMS-8 m.p.: $>119{ }^{\circ} \mathrm{C}$ (decomposition); ${ }^{1} \mathrm{H}$ NMR $\left(\mathrm{CDCl}_{3}, 300 \mathrm{MHz}\right): \delta=0.27\left(\mathrm{~s}, \mathrm{Si}\left(\mathrm{CH}_{3}\right)_{3}, 9 \mathrm{H}\right), 4.13$ (s, $\left.\mathrm{OCH}_{3}, 3 \mathrm{H}\right), 7.27(\mathrm{~d}, J=9.1 \mathrm{~Hz}, \mathrm{Ar}-H, 1 \mathrm{H}), 7.43$ (ddd, $J=8.1,6.9,1.2 \mathrm{~Hz}, \mathrm{Ar}-H, 1 \mathrm{H}), 7.60-7.69$ (m, Ar- $H, 2 \mathrm{H})$, 7.74 (ddd, $J=8.5,6.9,1.3 \mathrm{~Hz}, \operatorname{Ar}-H, 1 \mathrm{H}), 7.79$ (d, $J=8.2 \mathrm{~Hz}, \operatorname{Ar}-H, 1 \mathrm{H}), 7.84-7.90(\mathrm{~m}, \mathrm{Ar}-H, 3 \mathrm{H}), 8.27$ (d, $J=8.6 \mathrm{~Hz}, \mathrm{Ar}-H, 1 \mathrm{H}), 8.94(\mathrm{dd}, J=8.6,1.2 \mathrm{~Hz}, \operatorname{Ar}-H$, $1 \mathrm{H}), 9.19(\mathrm{~d}, J=8.0 \mathrm{~Hz}, \operatorname{Ar}-H, 1 \mathrm{H}) \mathrm{ppm} ;{ }^{13} \mathrm{C} \mathrm{NMR}$ $\left(\mathrm{CDCl}_{3}, 75 \mathrm{MHz}\right): \delta=-0.6\left(\mathrm{Si}\left(\mathrm{CH}_{3}\right)_{3}\right), 56.7\left(\mathrm{OCH}_{3}\right), 96.2$ (CCCC), 98.3 (CCCC), $100.9 \quad\left(\mathrm{CCSi}\left(\mathrm{CH}_{3}\right)_{3}\right), \quad 102.4$ $\left(C \mathrm{Si}\left(\mathrm{CH}_{3}\right)_{3}\right), 106.8(\mathrm{Ar}-\mathrm{C}), 112.4(\mathrm{Ar}-\mathrm{C}), 123.1(\mathrm{Ar}-\mathrm{C})$, 124.5 (Ar-C), 126.3 (Ar-C), 127.3 (Ar-C), 127.7 (Ar-C), 127.8 (Ar-C), $128.0(\mathrm{Ar}-C), 128.1$ (Ar-C), $128.2(\mathrm{Ar}-C)$, $128.6(\mathrm{Ar}-C), 128.8(\mathrm{Ar}-C), 129.1(\mathrm{Ar}-C), 131.3(\mathrm{Ar}-C)$, 133.9 (Ar-C), 134.7 (Ar-C), $135.0(\mathrm{Ar}-C), 135.2(\mathrm{Ar}-\mathrm{C})$, $160.4\left(\mathrm{Ar}-\mathrm{COCH}_{3}\right), 177.4$ (CO) ppm; HRMS (ESI): $\left(\left[\mathrm{C}_{29} \mathrm{H}_{24} \mathrm{O}_{2} \mathrm{Si}\right]+\mathrm{H}\right)^{+}$calc. 433.1618, found 433.1617; $\left(\left[\mathrm{C}_{29} \mathrm{H}_{24} \mathrm{O}_{2} \mathrm{Si}\right]+\mathrm{Na}\right)^{+}$calc. 455.1438 , found 455.1438 .

Compound 8 m.p.: $>149{ }^{\circ} \mathrm{C}$ (decomposition); ${ }^{1} \mathrm{H}$ NMR $\left(\mathrm{CDCl}_{3}, 300 \mathrm{MHz}\right): \delta=3.50(\mathrm{~s}, \mathrm{CCH}, 1 \mathrm{H}), 4.18(\mathrm{~s}$, $\mathrm{OCH}_{3}, 3 \mathrm{H}$ ), 7.32 (d, $\left.J=9.1 \mathrm{~Hz}, \mathrm{Ar}-H, 1 \mathrm{H}\right), 7.44$ (ddd, $J=8.2,6.9,1.2 \mathrm{~Hz}, \operatorname{Ar}-H, 1 \mathrm{H}), 7.63-7.75(\mathrm{~m}, \mathrm{Ar}-H, 3 \mathrm{H})$, $7.81(\mathrm{~d}, J=8.1 \mathrm{~Hz}, \mathrm{Ar}-H, 1 \mathrm{H}), 7.87-7.92(\mathrm{~m}, \mathrm{Ar}-H, 3 \mathrm{H})$, 8.29 (d, $J=8.7 \mathrm{~Hz}, \mathrm{Ar}-H, 1 \mathrm{H}), 8.91$ (d, $J=8.4 \mathrm{~Hz}, \mathrm{Ar}-H$, $1 \mathrm{H}), \quad 9.18-9.23(\mathrm{~m}, \mathrm{Ar}-H, 1 \mathrm{H})$ ppm; HRMS (ESI): $\left(\left[\mathrm{C}_{26} \mathrm{H}_{16} \mathrm{O}_{2}\right]+\mathrm{H}\right)^{+}$calc. 361.1223, found 361.1225; $\left(\left[\mathrm{C}_{26} \mathrm{H}_{16} \mathrm{O}_{2}\right]+\mathrm{Na}\right)^{+}$calc. 383.1043, found 383.1043.

(R)-1-[1-[(2-Methoxynaphthalen-1-yl)ethynyl]naphthalen2-yl]prop-2-yn-1-ol $\left(\mathbf{9}, \mathrm{C}_{26} \mathrm{H}_{18} \mathrm{O}_{2}\right)$

Two-step procedure from TMS-8: Reduction A solution of $0.40 \mathrm{~g}$ TMS-8 $(0.93 \mathrm{mmol})$ in $20 \mathrm{~cm}^{3}$ THF was reacted under inert conditions with $3.30 \mathrm{~cm}^{3}(R)$-Alpine-Borane ${ }^{\circledR}$ (1.17 mmol, $0.5 \mathrm{M}$ in THF) for 6 days at room temperature. Acetaldehyde $\left(0.10 \mathrm{~cm}^{3}, 1.8 \mathrm{mmol}\right)$ was added to quench the reaction and the mixture heated to $40{ }^{\circ} \mathrm{C}$ for $1 \mathrm{~h}$. After removal of volatile components in vacuo the oily residue was dissolved in $\mathrm{Et}_{2} \mathrm{O}$, the solution cooled to $0{ }^{\circ} \mathrm{C}$ 
and $0.25 \mathrm{~cm}^{3}$ ethanolamine $(4.17 \mathrm{mmol})$ added. After 20 min ethyl acetate was added and the resulting organic phase washed with water and brine. The phase was dried over $\mathrm{Na}_{2} \mathrm{SO}_{4}$ and the solvent evaporated.

Deprotection The residue was directly subjected to deprotection and, therefore, dissolved in a mixture of THF and methanol $\left(15 \mathrm{~cm}^{3}\right.$ each) and $484 \mathrm{mg} \mathrm{KF}(8.33 \mathrm{mmol})$ added as solid. The reaction mixture was stirred at room temperature for $48 \mathrm{~h}$ until TLC control indicated complete consumption of the starting material. The mixture was diluted with $30 \mathrm{~cm}^{3}$ water and extracted several times with ethyl acetate. The combined organic phases were washed with water and brine and dried over $\mathrm{Na}_{2} \mathrm{SO}_{4}$. Purification by chromatography on silica gel (cyclohexane:ethyl acetate $6: 1 \mathrm{v} / \mathrm{v})$ gave the pure product $9(321 \mathrm{mg}, 96 \%$ yield over two steps).

Reduction from compound 8 A solution of $0.17 \mathrm{~g} 8$ $(0.47 \mathrm{mmol})$ in $12 \mathrm{~cm}^{3}$ THF was mixed under inert conditions with $1.70 \mathrm{~cm}^{3}(R)$-Alpine-Borane ${ }^{\circledR}(0.85 \mathrm{mmol}$, $0.5 \mathrm{M}$ in THF) and allowed to react for 6 days at room temperature. Acetaldehyde $\left(0.05 \mathrm{~cm}^{3}, 0.9 \mathrm{mmol}\right)$ was added to quench the reaction and the mixture heated to $40{ }^{\circ} \mathrm{C}$ for $1 \mathrm{~h}$. After the removal of volatile components in vacuo the oily residue was dissolved in $6 \mathrm{~cm}^{3} \mathrm{Et}_{2} \mathrm{O}$, the solution cooled to $0{ }^{\circ} \mathrm{C}$ and $0.12 \mathrm{~cm}^{3}$ ethanolamine $(1.80 \mathrm{mmol})$ added. After 20 min ethyl acetate was added and the resulting organic phase washed with water and brine. The phase was dried over $\mathrm{Na}_{2} \mathrm{SO}_{4}$ and the solvent evaporated. The residue was purified by chromatography on silica gel (cyclohexane/ethyl acetate $6: 1 \mathrm{v} / \mathrm{v}$ ) to give pure product 9 (166 $\mathrm{mg}, 96 \%$ yield).

$[\alpha]_{\mathrm{D}}^{23}=-25.0^{\circ}\left(c=0.934, \mathrm{CHCl}_{3}\right) ;{ }^{1} \mathrm{H}$ NMR $\left(\mathrm{CDCl}_{3}\right.$, $300 \mathrm{MHz}): \delta=2.72(\mathrm{~d}, J=2.3 \mathrm{~Hz}, \mathrm{CH}, 1 \mathrm{H}), 4.15(\mathrm{~s}$, $\mathrm{OCH}_{3}, 3 \mathrm{H}$ ), 4.08 (bs, $\left.\mathrm{HCOH}, 1 \mathrm{H}\right), 6.33$ (bs, $H \mathrm{COH}, 1 \mathrm{H}$ ), $7.34(\mathrm{~d}, J=9.2 \mathrm{~Hz}$, Ar- $H, 1 \mathrm{H}), 7.45$ (ddd, $J=8.2,6.9$, $1.2 \mathrm{~Hz}, \mathrm{Ar}-H, 1 \mathrm{H}$ ), 7.57 (ddd, $J=8.1,6.8,1.3 \mathrm{~Hz}, \mathrm{Ar}-H$, $1 \mathrm{H}), 7.63-7.71(\mathrm{~m}, \mathrm{Ar}-H, 2 \mathrm{H}), 7.85(\mathrm{~d}, J=8.1 \mathrm{~Hz}, \mathrm{Ar}-H$, 1H), 7.87-7.93 (m, Ar- $H, 4 \mathrm{H}), 8.49$ (d, $J=8.4 \mathrm{~Hz}, \mathrm{Ar}-H$, $1 \mathrm{H}), 8.70(\mathrm{~d}, J=8.4 \mathrm{~Hz}, \operatorname{Ar}-H, 1 \mathrm{H}) \mathrm{ppm} ;{ }^{13} \mathrm{C} \mathrm{NMR}$ $\left(\mathrm{CDCl}_{3}, 75 \mathrm{MHz}\right): \delta=56.7\left(\mathrm{OCH}_{3}\right), 64.0(\mathrm{HCOH}), 75.2$ $(\mathrm{CCH}), 83.0(\mathrm{CCH}), 94.8$ (Ar-CCCC-Ar), 95.9 (Ar-CCCC$\mathrm{Ar}), 106.3(\mathrm{Ar}-C), 112.4(\mathrm{Ar}-\mathrm{C}), 119.8(\mathrm{Ar}-\mathrm{C}), 124.6$ (2x Ar-C), $125.4(\mathrm{Ar}-C), 126.8$ (Ar-C), $126.9(\mathrm{Ar}-C), 127.4$ (Ar-C), 128.0 (Ar-C), 128.4 (2x Ar-C), 128.7 (Ar-C), 129.0 (Ar-C), 130.9 (Ar-C), 133.2 (Ar-C), 133.3 (Ar-C), 134.1 (Ar-C), $140.7(\mathrm{Ar}-\mathrm{C}), 159.6\left(\mathrm{COCH}_{3}\right)$ ppm; HRMS (ESI): $\left(\left[\mathrm{C}_{26} \mathrm{H}_{18} \mathrm{O}_{2}\right]+\mathrm{Na}\right)^{+}$calc. 385.1199, found 383.1200.

General procedures for cyclization reactions under thermal and photochemical conditions

Cyclization cond. A A thermostated photochemical reactor was loaded with catalyst CAT1 under inert conditions and a solution of diyne 8 or 9 in $15 \mathrm{~cm}^{3}$ THF was added, followed by the appropriate nitrile. The reaction mixture was irradiated for $24 \mathrm{~h}$ at $25{ }^{\circ} \mathrm{C}$ using medium-pressure metal halide lamps $(2 \times 450 \mathrm{~W})$. For stopping the reaction the lamps were turned off and the reaction vessel opened to air. The reaction solution was filtered over Celite and the solvent was removed in vacuo. The crude product was purified by automated flash chromatography (cyclohexane/ethyl acetate, $100 \% \rightarrow 66 \%$ cyclohexane), yielding the pure product.

Cyclization cond. B In a Schlenk flask catalyst CAT2 was weighted under inert conditions, followed by addition of a solution of diyne 8 or 9 in $3 \mathrm{~cm}^{3}$ toluene and the appropriate nitrile. The reaction mixture was heated to $100{ }^{\circ} \mathrm{C}$ for $24 \mathrm{~h}$. After cooling the reaction solution was filtered over Celite and the solvent was removed in vacuo. The crude product was purified by automated flash chromatography (cyclohexane/ethyl acetate, $100 \% \rightarrow 66 \%$ cyclohexane), yielding the pure product.

(rac)-11-(2-Methoxynaphthalen-1-yl)-9-phenyl-7Hbenzo[6,7]indeno[1,2-c]pyridin-7-one $\left(\mathbf{1 0 a}, \mathrm{C}_{33} \mathrm{H}_{21} \mathrm{O}_{2}\right)$ Syntheses following cyclization cond. A Reacting $60 \mathrm{mg} 8$ $(0.17 \mathrm{mmol})$ with $3.88 \mathrm{mg}$ CAT1 $(16.7 \mu \mathrm{mol})$ and $85 \mathrm{~mm}^{3}$ PhCN $(0.83 \mathrm{mmol})$ gave biaryl 10a with $25 \%(19 \mathrm{mg})$ yield. Reacting $78 \mathrm{mg} 9(0.22 \mathrm{mmol})$ with $5.0 \mathrm{mg}$ CAT1 $(21.5 \mu \mathrm{mol})$ and $110 \mathrm{~mm}^{3} \mathrm{PhCN}(1.08 \mathrm{mmol})$ gave biaryl 10a with $70 \%(70 \mathrm{mg})$ yield.

Syntheses following cyclization cond. B Reacting $60 \mathrm{mg}$ $8(0.17 \mathrm{mmol})$ with $7.8 \mathrm{mg}$ CAT2 $(18 \mu \mathrm{mol})$ and $85 \mathrm{~mm}^{3}$ PhCN $(0.83 \mathrm{mmol})$ gave biaryl 10a with $30 \%(23 \mathrm{mg})$ yield. Reacting $100 \mathrm{mg} \mathbf{9}(0.28 \mathrm{mmol})$ with $12.8 \mathrm{mg}$ CAT2 $(29.5 \mu \mathrm{mol})$ and $140 \mathrm{~mm}^{3} \mathrm{PhCN}(1.38 \mathrm{mmol})$ gave biaryl 10a with $62 \%(80 \mathrm{mg})$ yield.

M.p.: $\quad 99-100{ }^{\circ} \mathrm{C} ; \quad{ }^{1} \mathrm{H} \quad \mathrm{NMR} \quad\left(\mathrm{CDCl}_{3}, 300 \mathrm{MHz}\right)$ : $\delta=3.25\left(\mathrm{~s}, \mathrm{OCH}_{3}, 3 \mathrm{H}\right), 6.59(\mathrm{ddd}, J=8.7,6.9,1.3 \mathrm{~Hz}$, $\operatorname{Ar}-H, 1 \mathrm{H}), 6.85(\mathrm{~d}, J=8.6 \mathrm{~Hz}, \operatorname{Ar}-H, 1 \mathrm{H}), 7.16(\mathrm{~d}$, $J=9.1 \mathrm{~Hz}$, Ar- $H, 1 \mathrm{H}), 7.29(\mathrm{ddd}, J=8.3 .6 .8,1.1 \mathrm{~Hz}$, Ar- $H, 1 \mathrm{H}), 7.41-7.54$ (m, Ar- $H, 5 \mathrm{H}), 7.69-7.85$ (m, Ar- $H$, 3H), 7.92-7.97 (m, Ar- $H, 1 \mathrm{H}), 8.02(\mathrm{~d}, J=9.1 \mathrm{~Hz}, \mathrm{Ar}-H$, 1H), $8.10(\mathrm{~s}, \mathrm{Ar}-\mathrm{H}, 1 \mathrm{H}), 8.12-8.17$ (m, Ar- $H, 3 \mathrm{H}) \mathrm{ppm} ;{ }^{13} \mathrm{C}$ NMR $\left(\mathrm{CDCl}_{3}, 75 \mathrm{MHz}\right): \delta=56.1\left(\mathrm{OCH}_{3}\right), 112.0(\mathrm{Ar}-\mathrm{C})$, 113.5 (Ar- $C$ ), 119.8 (Ar-C), 124.3 (Ar- $C), 124.6(\mathrm{Ar}-C)$, 125.6 (Ar-C), $126.3(\mathrm{Ar}-C), 126.5(\mathrm{Ar}-C), 127.1(2 \mathrm{x} \mathrm{Ph}-C)$, 127.5 (Ar-C), $128.1(\mathrm{Ar}-C), 128.6(\mathrm{Ar}-C), 128.9$ (2x Ar-C), 129.7 (Ar-C), 129.8 (Ar-C), $130.6(\mathrm{Ar}-C), 131.2(\mathrm{Ar}-C)$, 132.5 (Ar-C), $133.3(\mathrm{Ar}-C), 138.4$ (2x Ar-C), $138.7(\mathrm{Ar}-C)$, 144.0 (Ar-C), 146.9 (Ar-C), 149.3 (Ar-C), 155.1 (Ar-C), 158.3 (Ar-C), 194.0 (CO) ppm; HRMS (ESI): $\left(\left[\mathrm{C}_{33} \mathrm{H}_{21-}\right.\right.$ $\left.\left.\mathrm{NO}_{2}\right]+\mathrm{H}\right)^{+} \quad$ calc. 464.1645, found 464.1646; $\left(\left[\mathrm{C}_{33} \mathrm{H}_{21} \mathrm{NO}_{2}\right]+\mathrm{Na}\right)^{+}$calc. 468.1465 , found 468.1459; UV-Vis (THF, $c \approx 10^{-3}$ ): $\lambda_{\max }=245,285,294,299,468$ (broad signal) nm; IR (ATR): $\bar{v}=692,747,727,810$, 1072, 1246, 1260, 1367, $13811711 \mathrm{~cm}^{-1}$. 
(rac)-11-(2-Methoxynaphthalen-1-yl)-9-methyl-7Hbenzo[6,7]indeno[1,2-c]pyridin-7-one

(10b, $\mathrm{C}_{28} \mathrm{H}_{19} \mathrm{NO}_{2}$ )

Syntheses following cyclization cond. A Reacting $124 \mathrm{mg} 9$ $(0.34 \mathrm{mmol})$ with $7.9 \mathrm{mg}$ CAT1 $(34 \mu \mathrm{mol})$ and $90 \mathrm{~mm}^{3}$ MeCN (1.71 mmol) gave biaryl 10b with 69\% (95 mg) yield.

Syntheses following cyclization cond. B Reacting $100 \mathrm{mg} 9(0.27 \mathrm{mmol})$ with $12.8 \mathrm{mg}$ CAT2 $(29.5 \mu \mathrm{mol})$ and $73 \mathrm{~mm}^{3} \mathrm{MeCN}$ (1.38 mmol) gave biaryl 10b with $48 \%$ (53 mg) yield.

M.p.: $>224{ }^{\circ} \mathrm{C}$ (decomposition); ${ }^{1} \mathrm{H} \mathrm{NMR}\left(\mathrm{CDCl}_{3}\right.$, $300 \mathrm{MHz}): \delta=2.72\left(\mathrm{~s}, \mathrm{CCH}_{3}, 3 \mathrm{H}\right), 3.33\left(\mathrm{~s}, \mathrm{OCH}_{3}, 3 \mathrm{H}\right)$, 6.54 (ddd, $J=8.9,6.8,1.3 \mathrm{~Hz}, \operatorname{Ar}-H, 1 \mathrm{H}), 6.76$ (d, $J=8.6 \mathrm{~Hz}, \operatorname{Ar}-H, 1 \mathrm{H}), 7.19(\mathrm{~d}, J=9.1 \mathrm{~Hz}, \operatorname{Ar}-H, 1 \mathrm{H})$, 7.25 (ddd, $J=8.2,6.8,1.1 \mathrm{~Hz}$, Ar- $H, 1 \mathrm{H}), 7.36-7.49$ (m, Ar- $H, 3 \mathrm{H}), 7.65-7.81$ (m, Ar- $H, 3 \mathrm{H}), 7.84-7.93$ (m, Ar- $H$, $2 \mathrm{H}), 8.0(\mathrm{~d}, J=9.0 \mathrm{~Hz}, \mathrm{Ar}-H, 1 \mathrm{H}) \mathrm{ppm} ;{ }^{13} \mathrm{C} \mathrm{NMR}$ $\left(\mathrm{CDCl}_{3}, 75 \mathrm{MHz}\right): \delta=25.0\left(\mathrm{CCH}_{3}\right), 56.2\left(\mathrm{OCH}_{3}\right), 113.6$ (Ar-C), 115.6 (Ar-C), 119.7 (Ar-C), 124.3 (Ar-C), 124.5 $(\mathrm{Ar}-C), 125.2(\mathrm{Ar}-C), 126.3(\mathrm{Ar}-C), 126.5$ (Ar-C), 127.5 $(\mathrm{Ar}-C), 128.1$ (Ar-C), 128.3 (Ar-C), 128.5 (Ar-C), 128.9 (Ar-C), 129.7 (Ar-C), 130.5 (Ar-C), 131.1 (Ar-C), 132.2 (Ar-C), 133.2 (Ar-C), 137.5 (Ar-C), 138.4 (Ar-C), 143.3 (Ar-C), 146.9 (Ar-C), 149.0 (Ar-C), 155.0 (Ar-C), 160.7 $(\mathrm{Ar}-\mathrm{C}), 194.3$ (CO) ppm; HRMS (ESI): $\left(\left[\mathrm{C}_{28} \mathrm{H}_{19-}\right.\right.$ $\left.\left.\mathrm{NO}_{2}\right]+\mathrm{H}\right)^{+}$calc. 402.1489, found 402.1491; $\left(\left[\mathrm{C}_{28} \mathrm{H}_{19} \mathrm{NO}_{2}\right]+\mathrm{Na}\right)^{+}$calc. 424.1308, found 424.1308; IR (ATR): $\bar{v}=436,735,748,760,780,797,807,1244,1257$, $1713 \mathrm{~cm}^{-1}$.

(rac)-11-(2-Methoxynaphthalen-1-yl)-9-tert-butyl-7H-

benzo[6, 7]indeno-[1,2-c]pyridin-7-one

$\left(\mathbf{1 0 c}, \mathrm{C}_{31} \mathrm{H}_{25} \mathrm{NO}_{2}\right.$ )

Syntheses following cyclization cond. B: the reaction of $40 \mathrm{mg}$ diyne 9 (0.11 mmol), $5.1 \mathrm{mg} \mathrm{CAT2}$ (0.011 mmol), and $28 \mathrm{mg}$ tert-butylnitrile $(0.33 \mathrm{mmol})$ furnished biaryl 10c with $39 \%$ (19 mg) yield.

${ }^{1} \mathrm{H}$ NMR $\left(\mathrm{CDCl}_{3}, 300 \mathrm{MHz}\right): \delta=1.43\left(\mathrm{~s}, \mathrm{C}\left(\mathrm{CH}_{3}\right)_{3}\right.$, 9H), 3.18 (s, $\left.\mathrm{OCH}_{3}, 3 \mathrm{H}\right), 6.55$ (ddd, $J=8.8,6.8,1.4 \mathrm{~Hz}$, Ar- $H, 1 \mathrm{H}), 6.77$ (dd, $J=8.7,1.1 \mathrm{~Hz}, \operatorname{Ar}-H, 1 \mathrm{H}), 7.12$ (d, $J=9.1 \mathrm{~Hz}$, Ar- $H, 1 \mathrm{H}), 7.25(\mathrm{ddd}, J=8.2,6.8,1.1 \mathrm{~Hz}$, Ar- $H, 1 \mathrm{H}), 7.38-7.48$ (m, Ar- $H, 2 \mathrm{H}), 7.65$ (s, Ar- $H, 1 \mathrm{H})$, 7.66-7.73 (m, Ar- H, 2H), 7.78 (d, $J=8.2 \mathrm{~Hz}, \operatorname{Ar}-H, 1 \mathrm{H})$, $7.88-7.93$ (m, Ar- $H, 1 \mathrm{H}), 7.97$ (d, $J=9.1 \mathrm{~Hz}, \operatorname{Ar}-H, 1 \mathrm{H})$, 8.04-8.08 (m, Ar- $H, 1 \mathrm{H})$ ppm; ${ }^{13} \mathrm{C} \mathrm{NMR}\left(\mathrm{CDCl}_{3}\right.$, $75 \mathrm{MHz}): \quad \delta=30.1 \quad\left(\mathrm{C}\left(\mathrm{CH}_{3}\right)_{3}\right), \quad 38.4 \quad\left(\mathrm{C}\left(\mathrm{CH}_{3}\right)_{3}\right), \quad 56.2$ $\left(\mathrm{OCH}_{3}\right), 111.2(\mathrm{Ar}-\mathrm{C}), 113.9(\mathrm{Ar}-\mathrm{C}), 119.7$ (Ar-C), 124.2 (Ar-C), 125.9 (Ar-C), 126.2 (Ar-C), 126.5 (Ar-C), 127.1 $(\mathrm{Ar}-C), 128.0$ (Ar-C), $128.2(\mathrm{Ar}-C), 128.4$ (Ar-C), 128.8 $(\mathrm{Ar}-C), 129.7$ (Ar-C), $130.2(\mathrm{Ar}-C), 131.0(\mathrm{Ar}-C), 132.4$ $(\mathrm{Ar}-C), 133.3$ (Ar-C), 138.3 (Ar-C), 143.4 (Ar-C), 147.9
(Ar- $C$ ), 155.0 (Ar- $C$ ), $160.9(\mathrm{Ar}-C), 171.2$ (Ar- $C), 194.7$ $(C O)$ ppm (not all expected signals were found, possibly due to signal overlap); HRMS (ESI): $\left(\left[\mathrm{C}_{31} \mathrm{H}_{25} \mathrm{NO}_{2}\right]\right)^{+}$calc. 444.1958, found 444.1951.

(rac)-11-(2-Methoxynaphthalen-1-yl)-9-piperidinyl-7Hbenzo[6,7]indeno-[1,2-c]pyridin-7-one

(10d, $\mathrm{C}_{32} \mathrm{H}_{26} \mathrm{~N}_{2} \mathrm{O}_{2}$ )

Syntheses following cyclization cond. B Reacting $40 \mathrm{mg} 9$ (0.11 mmol) with $5.1 \mathrm{mg}$ CAT2 (0.011 mmol) and $40 \mathrm{~mm}^{3}$ 1-piperidinecarbonitrile $(0.33 \mathrm{mmol})$ gave biaryl 10d with $62 \%$ yield $(32 \mathrm{mg})$.

${ }^{1} \mathrm{H} \quad \mathrm{NMR} \quad\left(\mathrm{CDCl}_{3}, 300 \mathrm{MHz}\right): \delta=1.61-1.72 \quad(\mathrm{~m}$, $\left.\mathrm{C}_{5} \mathrm{H}_{10} \mathrm{~N}-\mathrm{H}, 6 \mathrm{H}\right), 3.30\left(\mathrm{~s}, \mathrm{OCH}_{3}, 3 \mathrm{H}\right), 3.66-3.75(\mathrm{~m}$, $\mathrm{C}_{5} \mathrm{H}_{10} \mathrm{~N}-H, 4 \mathrm{H}$ ), 6.50 (ddd, $J=8.7,6.7,1.3 \mathrm{~Hz}, \operatorname{Ar}-H$, $1 \mathrm{H}), 6.73(\mathrm{dd}, J=8.8,0.9 \mathrm{~Hz}, \mathrm{Ar}-H, 1 \mathrm{H}), 7.13$ (s, Ar- $H$, $1 \mathrm{H}), 7.16(\mathrm{~d}, J=9.1 \mathrm{~Hz}, \mathrm{Ar}-H, 1 \mathrm{H}), 7.22$ (ddd, $J=8.3$, 6.8, $1.2 \mathrm{~Hz}, \operatorname{Ar}-H, 1 \mathrm{H}), 7.36-7.46$ (m, Ar- H, 2H), 7.57 (d, $J=8.2 \mathrm{~Hz}, \operatorname{Ar}-H, 1 \mathrm{H}), 7.63(\mathrm{~d}, J=8.2 \mathrm{~Hz}, \operatorname{Ar}-H, 1 \mathrm{H})$, $7.73(\mathrm{~d}, J=8.3 \mathrm{~Hz}, \operatorname{Ar}-H, 1 \mathrm{H}), 7.87-7.91$ (m, Ar- $H, 1 \mathrm{H})$, $7.96(\mathrm{~d}, J=9.1 \mathrm{~Hz}, \operatorname{Ar}-H, 1 \mathrm{H}), 8.08-8.11(\mathrm{~m}, \mathrm{Ar}-H, 1 \mathrm{H})$ ppm; ${ }^{13} \mathrm{C} \mathrm{NMR}\left(\mathrm{CDCl}_{3}, 75 \mathrm{MHz}\right): \delta=24.8\left(\mathrm{C}_{5} \mathrm{H}_{10} \mathrm{~N}-C\right)$, $25.7\left(2 \mathrm{x} \mathrm{C}_{5} \mathrm{H}_{10} \mathrm{~N}-C\right), 46.3\left(2 \mathrm{x}_{5} \mathrm{H}_{10} \mathrm{~N}-C\right), 56.2\left(\mathrm{OCH}_{3}\right)$, 100.8 (Ar-C), 113.8 (Ar-C), 119.7 (Ar-C), 123.9 (Ar-C), 125.5 (Ar- $C$ ), 125.8 (Ar- $C$ ), 126.7 (Ar- $C$ ), 126.8 (Ar- $C$ ), 126.9 (Ar-C), 127.7 (Ar-C), 128.0 (2x Ar-C), 128.2 (Ar- $C$ ), 128.5 (Ar- $C$ ), 129.4 (Ar-C), 130.4 (Ar- $C$ ), 131.5 (Ar- $C$ ), 133.3 (Ar- $C$ ), 138.3 (Ar-C), 145.6 (Ar- $C$ ), 148.8 (Ar- $C$ ), 154.7 (Ar- $C$ ), 158.6 (Ar- $C$ ), 194.6 (CO) ppm (not all expected signals could be observed individually); HRMS (ESI): $\left(\left[\mathrm{C}_{32} \mathrm{H}_{26} \mathrm{~N}_{2} \mathrm{O}_{2}\right]+\mathrm{H}\right)^{+}$calc. 471.2067, found 471.2059.

(rac)-11-(2-Methoxynaphthalen-1-yl)-9-(naphthalen-1-yl)7H-benzo[6,7]-indeno[1,2-c]pyridin-7-one

(10e, $\mathrm{C}_{37} \mathrm{H}_{23} \mathrm{NO}_{2}$ )

Syntheses following cyclization cond. B: the reaction of $50 \mathrm{mg}$ diyne $9 \quad(0.137 \mathrm{mmol}), \quad 6.4 \mathrm{mg} \quad$ CAT2 $(0.0137 \mathrm{mmol}), \quad$ and $\quad 42.3 \mathrm{mg}$ 1-naphthonitrile $(0.276 \mathrm{mmol})$ under the original conditions of cond. B gave biaryl 10b with $17 \%$ yield $(12 \mathrm{mg})$.

Alternative syntheses following cyclization cond. B (instead of conventional heating microwave heating (MW) was applied: $\left.1 \mathrm{~h}, 110{ }^{\circ} \mathrm{C}, 200 \mathrm{~W}\right)$ : A solution of $40 \mathrm{mg}$ diyne 9 (0.11 mmol) with $5.1 \mathrm{mg}$ CAT2 (0.011 mmol), and $34 \mathrm{mg}$ 1-naphthonitrile $(0.22 \mathrm{mmol})$ in $3 \mathrm{~cm}^{3}$ toluene yielded upon microwave irradiation $21 \mathrm{mg}$ of biaryl 10e (37\% yield).

${ }^{1} \mathrm{H}$ NMR $\left(\mathrm{CDCl}_{3}, 300 \mathrm{MHz}\right): \delta=3.50\left(\mathrm{~s}, \mathrm{OCH}_{3}, 3 \mathrm{H}\right)$, 6.60 (ddd, $J=8.7,6.8,1.4 \mathrm{~Hz}, \operatorname{Ar}-H, 1 \mathrm{H}), 6.94$ (dd, $J=8.7,1.0 \mathrm{~Hz}$, Ar- $H, 1 \mathrm{H}), 7.23-7.31$ (m, Ar- $H, 2 \mathrm{H}), 7.37$ (ddd, $J=8.0,6.9,1.2 \mathrm{~Hz}, \operatorname{Ar}-H, 1 \mathrm{H}), 7.44(\mathrm{ddd}, J=8.5$, 6.8, $1.4 \mathrm{~Hz}$, Ar- $H, 1 \mathrm{H}), 7.49-7.59$ (m, Ar- H, 3H), 7.71 (d, 
$J=8.2 \mathrm{~Hz}, \operatorname{Ar}-H, 1 \mathrm{H}), 7.79(\mathrm{~d}, J=8.1 \mathrm{~Hz}, \operatorname{Ar}-H, 1 \mathrm{H})$, 7.82 (dd, $J=7.2,1.3 \mathrm{~Hz}$, Ar- $H, 1 \mathrm{H}), 7.84-7.93$ (m, Ar- $H$, $4 \mathrm{H}), 7.97-8.03(\mathrm{~m}, \mathrm{Ar}-H, 3 \mathrm{H}), 8.41-8.45(\mathrm{~m}, \mathrm{Ar}-\mathrm{H}, 1 \mathrm{H})$ ppm; ${ }^{13} \mathrm{C}$ NMR $\left(\mathrm{CDCl}_{3}, 75 \mathrm{MHz}\right): \delta=56.3\left(\mathrm{OCH}_{3}\right)$, 113.5 (Ar-C), $117.0(\mathrm{Ar}-\mathrm{C}), 119.8(\mathrm{Ar}-\mathrm{C}), 124.2(\mathrm{Ar}-\mathrm{C})$, $125.2(\mathrm{Ar}-C), 125.5(\mathrm{Ar}-\mathrm{C}), 125.9(\mathrm{Ar}-\mathrm{C}), 126.1(\mathrm{Ar}-\mathrm{C})$, $126.5(\mathrm{Ar}-C), 126.6(\mathrm{Ar}-C), 126.8(\mathrm{Ar}-C), 127.5(\mathrm{Ar}-C)$, 127.8 (Ar- $C$ ), 128.3 (2x Ar- $C$ ), 128.6 (2x Ar- $C), 129.0$ (ArC), $129.5(\mathrm{Ar}-C), 129.7(\mathrm{Ar}-C), 130.9(\mathrm{Ar}-C), 131.2(2 \mathrm{x}$ $\mathrm{Ar}-\mathrm{C}), 132.5$ (Ar-C), 133.3 (Ar-C), $134.2(\mathrm{Ar}-\mathrm{C}), 138.4$ (Ar-C), 138.6 (Ar-C), 143.4 (Ar-C), 146.5 (Ar-C), 149.5 (Ar-C), 155.1 (Ar-C), 160.9 (Ar-C), 194.0 (CO) ppm (not all expected signals could be observed individually); HRMS (ESI): $\left(\left[\mathrm{C}_{37} \mathrm{H}_{23} \mathrm{NO}_{2}\right]+\mathrm{H}\right)^{+}$calc. 514.1802, found 514.1795 .

Acknowledgements Open access funding provided by Johannes Kepler University Linz. We thank the LIKAT and the Leibniz-Gemeinschaft for financial support. The excellent technical support from the analytical department (NMR: Dipl.-Ing. Andreas Koch and Susann Buchholz) is gratefully acknowledged. We would like to thank Dr. Anke Spannenberg for supplying the molecular structure of compound 4.

Open Access This article is distributed under the terms of the Creative Commons Attribution 4.0 International License (http:// creativecommons.org/licenses/by/4.0/), which permits unrestricted use, distribution, and reproduction in any medium, provided you give appropriate credit to the original author(s) and the source, provide a link to the Creative Commons license, and indicate if changes were made.

\section{References}

1. Bringmann G, Gulder T, Gulder TAM, Breuning M (2011) Chem Rev 111:563

2. Bringmann G, Price Mortimer AJ, Keller PA, Gresser MJ, Garner J, Breuning M (2005) Angew Chem Int Ed 44:5384
3. Bringmann G, Tasler S, Pfeifer R-M, Breuning M (2002) J Organomet Chem 661:49

4. LaPlante SR, Edwards PJ, Fader LD, Jakalian A, Hucke O (2011) ChemMedChem 6:505

5. LaPlante SR, Fader LD, Fandrick KR, Fandrick DR, Hucke O, Kemper R, Miller SPF, Edwards PJ (2011) J Med Chem 54:7005

6. McCarthy M, Guiry PJ (2001) Tetrahedron 57:3809

7. Li Y-M, Kwong F-Y, Yu W-Y, Chan ASC (2007) Coord Chem Rev 251:2119

8. Lühr S, Holz J, Börner A (2011) ChemCatChem 3:1708

9. Wallace TW (2006) Org Biomol Chem 4:3197

10. Shen Y, Chen C-F (2012) Chem Rev 112:1463

11. Gingras M (2013) Chem Soc Rev 42:968

12. Gingras M, Felix G, Peresutti R (2013) Chem Soc Rev 42:1007

13. Gingras M (2013) Chem Soc Rev 42:1051

14. Tanaka K (ed) (2013) Transition-metal-mediated aromatic ring construction. Wiley, Hoboken

15. Tanaka K (2009) Chem Asian J 4:508

16. Sehnal P, Krausová Z, Teplý F, Stará IG, Starý I, Rulisek L, Šaman D, Císařová I (2008) J Org Chem 73:2074

17. Shibata T, Uchiyama T, Yoshinami Y, Takayasu S, Tsuchikama K, Endo K (2012) Chem Commun 48:1311

18. Crittall MR, Fairhurst NWG, Carbery DR (2012) Chem Commun 48:11181

19. Hapke M, Kral K, Fischer C, Spannenberg A, Gutnov A, Redkin D, Heller B (2010) J Org Chem 75:3993

20. Jungk P, Täufer T, Thiel I, Hapke M (2016) Synthesis 48:2026

21. Fischer F, Siegle AF, Checinski M, Fischer C, Kral K, Thede R, Trapp O, Hapke M (2016) J Org Chem 81:3087

22. Heller B, Hapke M, Fischer C, Andronova A, Starý I, Stará IG (2013) J Organomet Chem 723:98

23. Fischer F, Jungk P, Weding N, Spannenberg A, Ott H, Hapke M (2012) Eur J Org Chem 5828

24. Iskra J, Stauber S, Zupan M (2004) Synthesis 1869

25. Weber E, Csöregh I, Stensland B, Czugler M (1984) J Am Chem Soc 106:3297

26. Wessig P, Müller G (2006) Chem Commun 4524

27. Stará IG, Starý I, Kollárovič A, Teplý F, Šaman D, Fiedler P (1998) Tetrahedron 54:11209

28. Niu T, Wang K-H, Huang D, Xu C, Su Y, Hu Y, Fu Y (2014) Synthesis $46: 320$

29. Thiel I, Spannenberg A, Hapke M (2013) ChemCatChem 5:2865 